\title{
Changes in Human Serum Amyloid A and C-Reactive Protein after Etiocholanolone-Induced Inflammation
}

\author{
KeITH P. W. J. MCADAM, Immunology Branch, National Cancer Institute, National \\ Institutes of Health, Bethesda, Maryland 20014 \\ Ronald J. Elin, Clinical Pathology Department, Clinical Center, National Institutes \\ of Health, Bethesda, Maryland 20014 \\ JEAN D. SIPE, Laboratory of Experimental Pathology, National Institute of Arthritis, \\ Metabolism, and Digestive Diseases, National Institutes of Health, Bethesda, \\ Maryland 20014 \\ SHELdON M. WOLFF, Laboratory of Clinical Investigation, National Institute of \\ Allergy and Infectious Disease, National Institutes of Health, Bethesda, \\ Maryland 20014
}

A B S T RACT Secondary amyloidosis is a complication of diseases characterized by recurrent acute inflammation. In this study, a standardized stimulus which induced fever and inflammation was given to six normal subjects (19-24 yr old) to follow the fluctuation in concentration of serum amyloid A (SAA), the precursor of the secondary amyloid fibril protein. After a single intramuscular injection of etiocholanolone $(0.3 \mathrm{mg} / \mathrm{kg})$, blood samples were drawn twice a day for 12 days for determination of SAA by solid phase radioimmunoassay. From a base line of $<100 \mu \mathrm{g} / \mathrm{ml}$, the SAA concentration began rising within $12 \mathrm{~h}$ to a maximum value at about $48 \mathrm{~h}$ of $1,350-1,800 \mu \mathrm{g} / \mathrm{ml}$ in three males and $380-900 \mu \mathrm{g} / \mathrm{ml}$ in three females and returned to base line by 4-5 days. The SAA response showed a similar time response to C-reactive protein (CRP), a well-documented acute phase protein which was assayed semiquantitatively by capillary tube precipitin reaction. CRP, but not SAA, showed a quantitative correlation with the amount of fever induced by etiocholanolone. One subject exhibited a second rise in SAA and CRP concentrations after acute over-indulgence with alcohol, suggesting that acute liver damage may have caused an acute phase reaction. Thus, a controlled episode of fever and inflammation produced a prompt and prolonged elevation of SAA and CRP concentrations. Unlike SAA, CRP has not been implicated in the pathogenesis of

Address reprint requests to Doctors McAdam or Wolff at their new address: Tufts-New England Medical Center, Department of Medicine, Boston, Mass. 02111.

Received for publication 27 May 1977 and in revised form 16 September 1977. amyloidosis, although its relationship to the $\mathrm{P}$ component of amyloid has recently been established.

\section{INTRODUCTION}

Recent studies have suggested that a protein in serum identified by its cross-reaction with antibodies raised to the secondary amyloid fibril protein AA (1) and hence designated serum amyloid A (SAA) ${ }^{1}$ may be an acute phase reactant $(2,3)$.

SAA is a normal $\alpha$-globulin which can be detected in nanogram quantities by radioimmunoassay $(3,4)$. Elevated serum concentrations are found in association with diseases that cause secondary amyloidosis $(3,5)$, and it initially seemed that SAA might be a marker for patients developing secondary amyloidosis. However, increased SAA concentrations have been documented during acute viral and bacterial infections, during acute exacerbations of arthritis, familial Mediterranean fever, immune complex-mediated reactions in leprosy, and in animals subjected to a variety of inflammatory and immunologic stimuli. Thus, SAA elevation cannot be used as a diagnostic marker for amyloidosis.

Etiocholanolone ( $3 \alpha$-hydroxy- $5 \beta$-androstan-17-one) is a naturally occurring steroid metabolite arising from androgens of gonadal and adrenocortical origin. It has no known hormonal activity but will regularly produce fever only in man when administered intramuscularly in its free unconjugated form (6). Char-

\footnotetext{
${ }^{1}$ Abbreviations used in this paper: AA, secondary amyloid fibril protein; CRP, C-reactive protein; SAA, serum amyloid A; SAAL, low molecular weight serum amyloid $\mathrm{A}$.
} 
acteristically, an i.m. injection of etiocholanolone produces a local inflammatory reaction which is followed in $6-8 \mathrm{~h}$ by fever. Being a nonantigenic human pyrogen, it has been used in studies of the pathogenesis of fever and "sterile" inflammation. For this reason it also provides an interesting model for the study of acute phase reactants.

Another acute phase serum protein, C-reactive protein (CRP) has long been used as a nonspecific indicator of disease activity and inflammation (7). In this study, we compared the fluctuations in SAA and CRP concentrations associated with a standardized, controlled inflammatory reaction and fever induced with etiocholanolone.

\section{METHODS}

Subjects. Three female and three male volunteers between the ages of 19 and $24 \mathrm{yr}$ participated in this study. Physical examination and laboratory studies were normal in all subjects. The subjects were not on any medication (including vitamins and anovulatory agents) for $2 \mathrm{wk}$ before and during the study. Informed consent was obtained from each volunteer.

Pyrogen. The steroid pyrogen etiocholanolone (Merck Chemical Div., Merck \& Co., Inc., Rahway, N. J.) was prepared for administration by the Pharmaceutical Development Service of the Pharmacy Department at the National Institutes of Health. The etiocholanolone was dissolved in the vehicle, propylene glycol (Fisher Scientific Co., Pittsburgh, Pa.), and given intramuscularly at a dose of $0.3 \mathrm{mg} / \mathrm{kg}$ body weight to induce a local inflammatory reaction with fever.

SAA estimation. Sera, stored at $-20^{\circ} \mathrm{C}$, were tested for SAA by solid-phase radioimmunoassay (4) with antibodies raised in rabbits to denatured amyloid fibrils and purified from the crude antiserum by affinity chromatography on a preparation of amyloid protein AA of single size and charge, and known $\mathrm{NH}_{2}$ terminal amino acid sequence (8). Previous studies have indicated that there are problems of reproducibility of SAA estimation in sera stored under varying conditions for different lengths of time. Native SAA (mol wt about 160,000) tends to both aggregate and dissociate in stored sera (9). When serum is incubated with formic acid, the high molecular weight SAA is dissociated to a species of more homogeneous and stable low molecular weight, referred to as low molecular weight SAA or SAAL (mol wt about 12,500). Formic acid treatment of sera yields higher SAA values than previously reported and has made it possible to obtain more reproducible values for SAA, presumably by dissociating protein-protein interactions $(9,10)$. Serum aliquots (10-25 $\mu \mathrm{l}$ ) were incubated in $500 \mu \mathrm{l}$ of $10 \%$ ( $\mathrm{vol} / \mathrm{vol}$ ) formic acid for $24 \mathrm{~h}$ at $37^{\circ} \mathrm{C}$ and $25-50 \mu \mathrm{l}$ of this mixture was diluted with water, frozen, lyophilized, and assayed in duplicate on flexible plastic microtitration plates which had been coated with anti-AA antibody. The only difference from the method published previously (4) was that instead of using a standard inhibition curve of AA protein on each microtitration plate, SAAL standards were used. In the past, SAA has been estimated in terms of AA cross reactivity, which on a weight-for-weight basis is about six to eight times more immunoreactive than SAAL. It has been shown that SAAL inhibition curves are parallel to those of SAA-rich serum and to the protein AA inhibition curves (9). Since the antibody was affinity purified to amyloid fibril protein
AA (mol wt 5,300), it reacts with shared determinants on SAAL, the putative serum precursor of the AA protein. SAAL was purified by descending gel filtration of serum from a patient with secondary amyloidosis, first at neutral $\mathrm{pH}$ on a Sephadex G-200 column (Pharmacia Fine Chemicals, Inc., Piscataway, N. J.) and then by applying the concentrated immunoreactive fractions from G-200 chromatography to a Sephadex G-100 column equilibrated in $10 \%$ formic acid, as described previously $(4,9)$.

CRP determination. The CRP determinations were performed with the semiquantitative precipitin test with CRP antiserum (7) purchased from Difco Laboratories, Detroit, Mich. (control number 629,855). CRP antiserum and test serum were combined in a capillary tube, incubated at $37^{\circ} \mathrm{C}$ for $24 \mathrm{~h}$, and the precipitate measured (slight precipitation, trace; $1-\mathrm{mm}$ precipitation, $1+$; $2-\mathrm{mm}$ precipitation, $2+; 3-\mathrm{mm}$ precipitation, 3+; 4-mm precipitation or greater, $4+$ ).

Experimental design. A blood sample for SAA and CRP determination was obtained from each subject at 8:00 a.m. and 8:00 p.m. daily for a 12 -day period. The lst day of the study established the base-line values. At midnight of the lst day of the study, each volunteer was given an intramuscular injection of etiocholanolone. During the 2nd day of the study, all volunteers were at bed rest and rectal temperatures were recorded every $30 \mathrm{~min}$ from 8:00 a.m. to 10:00 p.m. Intake of food and fluids was not controlled. On day 1 and after day 2 there were no restrictions on activities.

Data analyses. Febrile responses were quantified by three different parameters: the maximum temperature obtained with the pyrogenic agent, the maximum change in temperature between the base line and maximum temperature, and fever index, the area in square centimeters obtained by planimetry under the temperature curves. The individual temperature readings were plotted on graph paper where $1 \mathrm{~h}$ and $1^{\circ} \mathrm{C}$ each equalled 1 inch.

The index for SAA was derived by calculating the area under a curve for each SAA value using the trapezoidal rule with the value of the initial sample as the base line. The index for CRP was obtained by addition of the CRP results over the 12 days of the study. A CRP result of "trace" was given a value of 0.5 . The results for each study are expressed as the mean and the standard error of the mean. The Spearman rank correlation coefficient was used to make comparisons among the indices.

\section{RESULTS}

A large increase in the SAA concentration occurred after the fever induced by etiocholanolone. Base-line values were less than $100 \mu \mathrm{g} / \mathrm{ml}$ in all volunteers and SAA concentration started to increase $8-20 \mathrm{~h}$ after the administration of etiocholanolone. In males, a maximum concentration of $1,350-1,800 \mu \mathrm{g} / \mathrm{ml}$ was reached at $36-48 \mathrm{~h}$ after etiocholanolone, as compared with values ranging from 480 to $900 \mu \mathrm{g} / \mathrm{ml}$ in the females (Fig. 1). The males felt more discomfort at the injection site and had a higher, more prolonged episode of fever than the females (Table I) as previously described (6, 11). SAA concentrations returned to base-line values by 4 to 5 days after injection of the etiocholanolone (Figs. 1 and 2).

The CRP response followed a similar time course to that of the SAA response (Fig. 2). However, the correlation between the concentrations of SAA and 


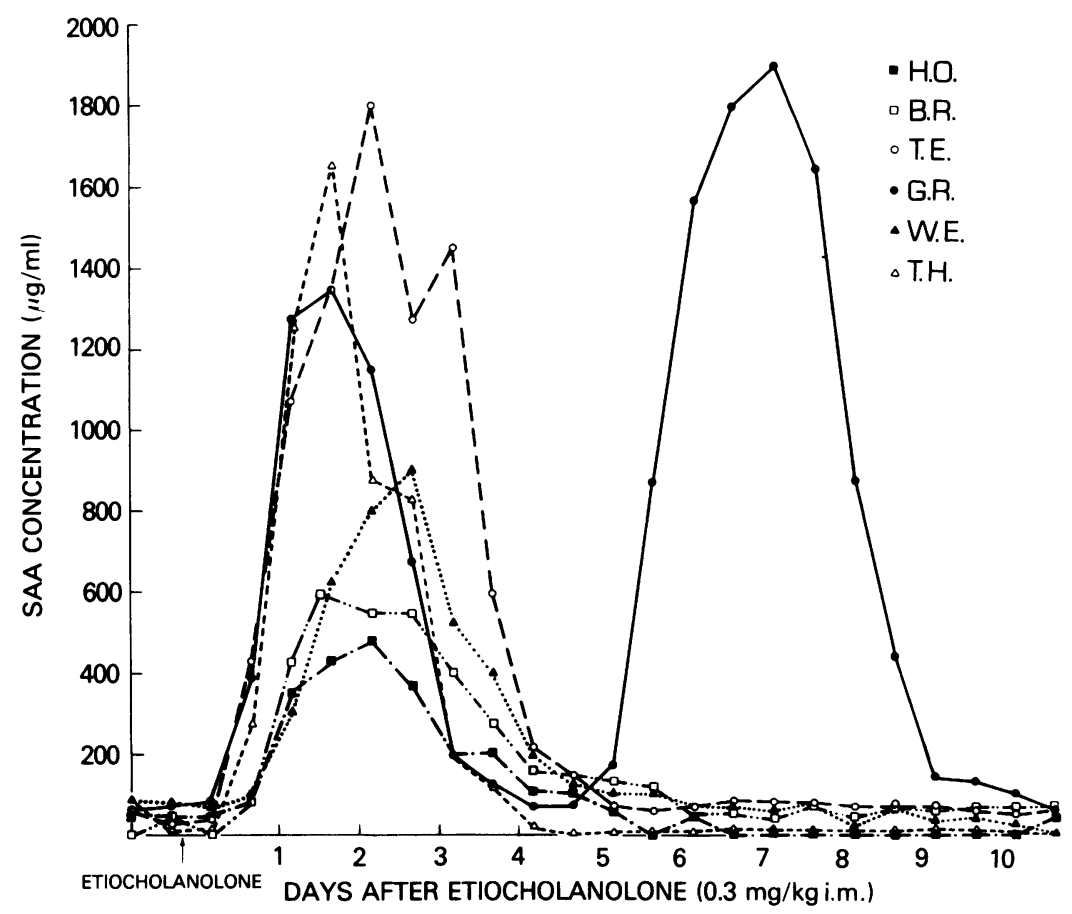

Figure 1 SAA responses of six volunteers after i.m. etiocholanolone $(0.3 \mathrm{mg} / \mathrm{kg})$. The second SAA rise in one individual (G. R.) was thought to be due to alcoholic intoxication.

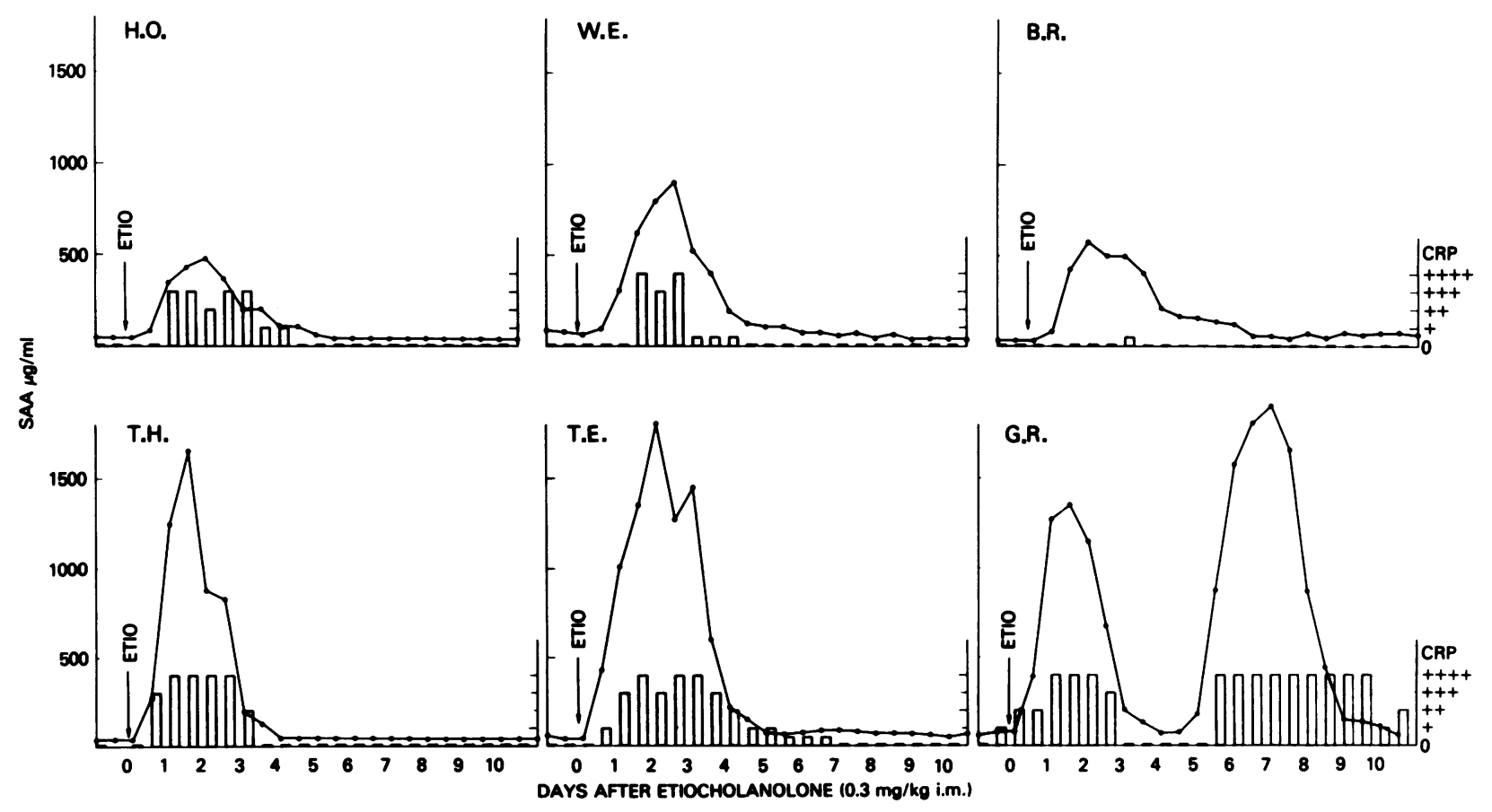

FIGURE 2 SAA and CRP response curves in each of six volunteers given i.m. etiocholanolone $0.3 \mathrm{mg} / \mathrm{kg}$ to show similar temporal responses of SAA and CRP. The females $\mathrm{H}$. O., W. E., and B. R. produced less SAA, CRP, and fever than the males T. H., T. E., and G. R. in response to the stimulus. 
TABLE I

Febrile, SAA, and CRP Responses in Each of Six Volunteers after i.m. Etiocholanolone $(0.3 \mathrm{mg} / \mathrm{kg})$

\begin{tabular}{|c|c|c|c|c|c|c|c|}
\hline \multirow[b]{2}{*}{ Subject } & \multirow[b]{2}{*}{ Age } & \multirow[b]{2}{*}{ Sex } & \multirow{2}{*}{$\begin{array}{l}\text { Temp } \\
\max \end{array}$} & \multirow{2}{*}{$\begin{array}{c}\Delta \\
\text { Temp }\end{array}$} & \multicolumn{3}{|c|}{ Indices } \\
\hline & & & & & Fever & SAA & CRP \\
\hline & $y r$ & & ${ }^{\circ} \mathrm{C}$ & ${ }^{\circ} \mathrm{C}$ & & & \\
\hline H. O. & 22 & F & 38.1 & 1.6 & 852 & 88 & 16 \\
\hline W. E. & 20 & F & 38.0 & 1.5 & 663 & 125 & 14 \\
\hline B. R. & 19 & $\mathrm{~F}$ & 38.2 & 1.7 & 200 & 137 & 1 \\
\hline G. R. & 24 & $M$ & 38.2 & 1.5 & 837 & $\begin{array}{l}205^{*} \\
594 \ddagger\end{array}$ & $\begin{array}{l}20^{*} \\
59 \ddagger\end{array}$ \\
\hline T. E. & 21 & M & 39.0 & 2.6 & 1,401 & 214 & 21 \\
\hline T. H. & 22 & $\mathbf{M}$ & 39.6 & 2.6 & 1,251 & 341 & 29 \\
\hline $\begin{array}{l}\text { Mean } \\
\text { SEM }\end{array}$ & & & $\begin{array}{r}38.5 \\
0.3\end{array}$ & $\begin{array}{l}1.9 \\
0.2\end{array}$ & $\begin{array}{l}867 \\
175\end{array}$ & $\begin{array}{r}185 \\
37\end{array}$ & $\begin{array}{r}16.8 \\
3.8\end{array}$ \\
\hline & Ranked & rrelation & & $\mathrm{r}$ & & $P$ value & \\
\hline & Feve & . SAA & & 0.54 & & $>0.20$ & \\
\hline & Feve & s. CRP & & 0.89 & & $<0.02$ & \\
\hline & SAA & CRP & & 0.77 & & $>0.05$ & \\
\hline
\end{tabular}

Temp max, maximum temperature obtained; $\Delta$ temp, maximum change in temperature between base line and Temp max. Indices for fever, SAA, and CRP were calculated as described in Methods and Spearman rank correlation coefficients were calculated for comparison of indices.

* SAA and CRP indices calculated for days 0-5.

$\$$ SAA and CRP indices calculated for entire study.

CRP as expressed by the SAA and CRP indices was not significant (Table I). This was particularly evident in the female volunteer B.R., who exhibited a rise in SAA concentration but no increase in CRP was detected by the precipitation method. When the volunteers were ranked by SAA, CRP, and fever indices, the correlation coefficient between fever index and CRP index was significant $(P<0.02)$, but between fever index and SAA index there was not a significant correlation $(P>0.2)$ (Table I).

One male volunteer (G.R.) was markedly dissimilar from the other five subjects in that he showed a secondary rise in SAA and CRP concentrations in the absence of any known stimulus. Careful retrospective scrutiny of the inpatient notes revealed no obvious cause: he was afebrile, there was no mention of a respiratory infection, and he was given no extra medication. When the individual was contacted by telephone, he recalled the study clearly and admitted that he had "broken bounds" during the middle of the study to go to a Nixon Inauguration Anniversary Ball and had returned much the worse for wear, intoxicated with alcohol. The secondary rise in SAA and CRP evidently followed this misadventure.

\section{DISCUSSION}

This study documents the acute phase nature of the SAA protein in man, after a controlled stimulus of acute inflammation and fever, and shows that there is close correlation between the temporal responses of SAA and CRP. SAA is presumed to be the circulating precursor $(12,13)$ of the AA protein by analogy with amyloidosis of immunoglobulin origin where the major fibril protein consists of intact immunoglobulin light chains or their variable region fragments (14). Diseases which predispose to secondary amyloidosis are characterized by recurrent episodes of acute inflammation, accompanied by fever, leukocytosis, and elevated concentrations of SAA (2). However, amyloidosis only occurs in a small percentage of patients found to have elevated SAA concentrations (3, 5) and the results of the present study show that high concentrations of SAA can be induced in previously asymptomatic individuals. It has not yet been established that tissue fibril AA originates directly from SAA by proteolytic modification; it may be that AA originates independently of SAA although they probably originate from a common gene product.

The rate and distribution of reticulo-endothelial clearance (15) and possibly the variable solubility of different sized complexes containing SAA may also help to explain why a normal acute phase protein forms insoluble amyloid fibrils in some circumstances. The physiological existence of the complexes is not established although SAA exists in different molecular forms (9) and associations have been demonstrated between $\mathrm{AA}$ and other serum proteins, including albumin (10), immunoglobulin light chain perhaps of limited subtypes (16), and the P component of amyloid (17). P component (plasma or pentagonal component) has been found in association with all types of amyloid deposits. Recent reports indicate amino acid sequence identity between $\mathrm{P}$ component and the presumed complement subunit $\mathrm{C}_{1} \mathrm{t}$ and limited sequence homology between these two and CRP, all of which possess similar pentagonal structures $(18,19)$.

The functional interrelationship between CRP and SAA after inflammation is unknown though both are reported to be suppressive in in vitro immunologic systems $(20,21)$. CRP exists in serum as a pentamer of $23,000 \mathrm{~mol}$ wt subunits which have a primary amino acid sequence distinct from SAAL, the 12,500 mol wt polypeptide obtained when native SAA of approximately $160,000 \mathrm{~mol}$ wt is treated with agents which dissociate noncovalent bonds. Several experiments suggest that CRP is synthesized by the liver after an inflammatory stimulus (22). In other studies 
from our laboratory, tissue homogenization of organs during the induction of an SAA response with intraperitoneal lipopolysaccharide showed that liver was the first organ in which AA immunoreactive material could be found (23). This finding might explain the unexpected response during the present study of volunteer G.R. after his alcoholic indulgence, which probably caused an acute hepatic insult. No tests of liver function or chest $\mathrm{X}$ ray were obtained at the time, and the only interpretable liver function test in retrospect (bilirubin) was normal, though this is not a sensitive marker of hepatic damage.

Thus, this study documents that SAA, like CRP, is an acute phase protein, having a similar time course after an acute inflammatory stimulus in man. However, it is still not established where such large quantities of SAA protein are being synthesized so rapidly after inflammation and, if the site of synthesis is indeed in the liver, what is the nature of the "messenger" between the local inflammatory lesion and the synthesizing cell.

\section{REFERENCES}

1. Levin, M., M. Pras, and E. C. Franklin. 1973. Immunologic studies of major nonimmunoglobulin protein of amyloid. I. Identification and partial characterization of a related serum component. J. Exp. Med. 138: 373-380.

2. McAdam, K. P. W. J., R. F. Anders, S. R. Smith, D. A. Russell, and M. A. Price. 1975. Association of amyloidosis with erythema nodosum leprosum reactions and recurrent neutrophil leucocytosis in leprosy. Lancet. II: 572-576.

3. Rosenthal, C. J., and E. C. Franklin. 1975. Variation with age and disease of an amyloid A protein-related serum component. J. Clin. Invest. 55: 746-753.

4. Sipe, J. D., T. F. Ignaczak, P. S. Pollock, and G. G. Glenner. 1976. Amyloid fibril protein AA: Purification and properties of the antigenically related serum component as determined by solid phase radioimmunoassay. J. Immunol. 116: 1151-1156.

5. Husby, G., and J. B. Natvig. 1974. A serum component related to nonimmunoglobulin amyloid protein, AS, a possible precursor of the fibrils. J. Clin. Invest. 53: $1054-1061$.

6. Wolff, S. M., H. R. Kimball, S. Perry, R. K. Root, and A. Kappas. 1967. The biological properties of etiocholanolone. Ann. Intern. Med. 6: 1268-1295.

7. Anderson, H. C., and M. McCarty. 1950. Determination of C-reactive protein in the blood as a measure of the activity of the disease process in acute rheumatic fever. Am. J. Med. 8: 445-455.

8. Linke, R. P., J. D. Sipe, P. S. Pollock, T. F. Ignaczak, and G. G. Glenner. 1975. Isolation of a low molecular weight serum component antigenically related to an amyloid fibril protein of unknown origin. Proc. Natl. Acad. Sci. U. S. A. 74: 1473-1476.
9. Sipe, J. D., K. P. W. J. McAdam, B. F. Torain, and G. G. Glenner, 1976. Conformational flexibility of the serum amyloid precursor SAA. Br. J. Exp. Pathol. 57: 582-592.

10. Franklin, E. C. 1976. Some properties of antisera to serum amyloid A protein (SAA): Inhibition of precipitation by complexing of SAA to albumin. J. Exp. Med. 144: 1679-1682.

11. Wolff, S. M., M. Rubenstein, J. H. Mulholland, and D. W. Alling. 1965. Comparison of hematologic and febrile response to endotoxin in man. Blood. 26: 190-201.

12. Rosenthal, C. J., E. C. Franklin, B. Frangione, and J. Greenspan. 1976. Isolation and partial characterization of SAA - an amyloid-related protein from human serum. $J$. Immunol. 116: 1415-1418.

13. Anders, R. F., J. B. Natvig, K. Stetten, G. Husby, and K. Norstoga. 1977. Amyloid-related serum protein SAA from three animal species: Comparison with human SAA. J. Immunol. 118: 229-234.

14. Glenner, G. G., and D. L. Page. 1976. Amyloid, amyloidosis, and amyloidogenesis. Int. Rev. Exp. Pathol. 15: 1-92.

15. Mannik, M., W. P. Arend, A. P. Hall, and B. C. Gilliland. 1971. Studies of antigen-antibody complexes. 1. Elimination of soluble complexes from rabbit circulation. J. Exp. Med. 133: 713-739.

16. Westermark, P., J. B. Natvig, R. F. Anders, K. Stetten, and G. Husby. 1976. Co-existence of protein AA and immunoglobulin light chain fragments in amyloid fibrils. Scand. J. Immunol. 5: 31-36.

17. Skinner, M., A. S. Cohen, T. Shirahama, and E. S. Cathcart. 1974. P component (pentagonal unit) of amyloid: isolation, characterization and sequence analysis. J. Lab. Clin. Med. 84: 604-614.

18. Osmand, A. P., B. Friedenson, H. Gewurz, R. H. Painter, T. Hoffman, and E. Shelton. 1977. Characterization of C-reactive protein and the complement subcomponent $\mathrm{C}_{1} \mathrm{t}$ as homologous proteins displaying cyclic pentamenic symmetry (pentraxins). Proc. Natl. cad. Sci. U. S. A. 74: 739-743.

19. Levo, Y., B. Frangione, and E. C. Franklin. 1977. Amino acid sequence similarities between amyloid $\mathrm{P}$ component, $\mathrm{C}_{1} \mathrm{t}$ and CRP. Nature (Lond.). 268: 56-57.

20. Croft, S. M., R. J. Mortensen, and H. Gewurz. 1976. Binding of C-Reactive protein to antigen-induced but not mitrogen-induced T lymphocytes. Science (Wash. D. C.). 193: 685-687.

21. Benson, M. D., M. A. Aldo-Benson, T. Shirahama, Y Borel, and A. S. Cohen. 1975. Suppression of in vitro antibody response by a serum factor (SAA) in experimentally induced amyloidosis. J. Exp. Med. 142: 236-241.

22. Hurlimann, J., G. J. Thorbecke, and J. M. Hochwald. 1966. The liver as the site of C-reactive protein formation. J. Exp. Med. 123: 365-378.

23. Sipe, J. D., K. P. W. J. McAdam, and F. Uchino. 1977. Biochemical evidence for the biphasic development of experimental amyloidosis. Lab Invest. In press. 